\title{
Spatial Analysis of Land Surface - Vegetation Relationship in Mountainous Areas of the Tropics Using Srtm-3 Dem
}

\author{
Joel Efiong ${ }^{1}$, Opaminola Nicholas Digha ${ }^{1}$ \& Obianuju Emmanuella Asouzu ${ }^{2}$ \\ ${ }^{1}$ Department of Geography and Environmental Science, University of Calabar, Calabar, Nigeria \\ ${ }^{2}$ Department of Geography and Environmental Management, University of Port Harcourt, Port Harcourt, \\ Nigeria \\ Correspondence: Joel Efiong, Department of Geography and Environmental Science, University of Calabar, P. M. \\ B. 1115, Calabar, Nigeria. Tel: 234-803-273-8080.E-mail: joel_efiong@yahoo.com
}

Received: November 3, 2015

Accepted: November 21, 2015

Online Published: May 24, 2016

doi:10.5539/jgg.v8n2p59

URL: http://dx.doi.org/10.5539/jgg.v8n2p59

\begin{abstract}
Digital elevation models (DEMs) have shown much potential for use in the extraction of land surface parameters and analysis of the relationship between land surface units and vegetation cover. However, there is lack of studies on the use of SRTM-3 DEM in vegetation studies of mountainous regions. This study is therefore an attempt to relate land surface parameters to vegetation cover in the Obudu mountain region using SRTM-3 DEM and Landsat data. Geomorphometric classification of the land surface was done using an unsupervised ISOCLUST algorithm while vegetation cover classification was done using the supervised approach based on the Maximum Likelihood algorithm. The resultant land surface units and vegetation cover maps were then related using grid-based statistic within the geographic information systems. The overall measure of difference between the two maps yielded a chi-square $($ d.f. $=24)=1.9154, p>0.05$. This implies that there is no significant difference between the land surface units and the vegetation cover in the study area. This findings support the use of SRTM-3 for land surface and vegetation mapping where there is no higher quality data, or the cost of obtaining one is inhibitive; a situation that is faced by many developing economies like Nigeria. However, this results should be interpreted and used within the context of the uncertainty that is contained in the SRTM-3 DEM.
\end{abstract}

Keywords: Spatial analysis, land surface-vegetation relationship, Obudu mountain region, SRTM-3 DEM, GIS, geomorphometry

\section{Introduction}

It has been argued that one of the most important factors for the development of vegetation cover over any land surface is relief (Florinsky \& Kuryakova, 1996). Moreover, literature (Hengl \& MacMillan, 2009) has shown that information on relief is often sufficient to produce reliable vegetation map, if other factors are held constant. Hence, land surface parameters (elevation, aspect and slope, etc.) are commonly used in vegetation mapping (Florinsky \& Kuryakova, 1996). These parameters could be combined to produce land surface units which are then related to vegetation cover. Although this could be achieved, the analysis of land surface parameters and land surface units derived from Shuttle Radar Topography Mission (SRTM)-3 DEM in relation to vegetation mapping in mountainous regions have not been adequately examined and documented.

Three main methodological approaches to analysing relationships between vegetation and environmental site factors are discernible in current Geographical Information Systems (GIS) literature (Höersch, Braun \& Schmidt, 2002). These are those that analyse relationships between vegetation and (i) direct influence of environmental site factors, (ii) entire set of environmental site factors, be it direct or indirect, and (iii) direct influence of environmental site factors based on the assumption that such influence can be reveal by land surface parameters. With the third approach, land surface derivatives and maps could provide useful information on the vegetation cover over mountainous regions. Such could assist in land and forest resource management efforts in mountainous areas.

The importance of remote sensing in obtaining data for land cover classification, particularly in difficult terrains has been acknowledged in literature (Lillesand, Kiefer \& Chipman, 2008; Mather \& Koch, 2011). However, 
cloud cover has always posed difficulty to the visible and the near infra-red remote sensing in many regions and particularly in the tropics (Langford \& Bell, 1997). An alternative to these remote sensors that take measurement within the visible and infra-red bands is radar; since wavelengths emitted by it are not attenuated by cloud cover and rain (Lillesand et al., 2008). Obtaining radar images is cost intensive and may be beyond the reach of many developing nations like Nigeria. However, the SRTM in 2000 has made the radar data available in DEM formats at no cost to the public. Land surface parameters can therefore be extracted from this DEM. Such parameters can be used to characterise the land surface of an area from where relationships with other environmental variables can be made.

Bolstad, Swank and Vose (1998) noted the importance of the physical environment in determining the spatial diversity of the land surface of mountainous regions. Höersch et al. (2002) and Abbate, Cavalli, Pascucci, Pignatti and Poscolieri (2006) concluded that there is a relationship between the vegetation types and topography in mountain areas. Hence, land surface parameters such as slope, aspect, profile curvature and plan curvature can be considered as important inputs in spatial analysis and estimation of the distribution of vegetation cover in mountainous environments.

In a recent study (Adediran, Parcharidis, Poscolieri \& Pavlopoulos, 2004), geomorphometric method that involved multivariate statistical analysis of topographic gradients proposed by Parcharidis, Pavlopoulos and Poscolieri (2001) was used to evaluate the morphological setting that surround each pixel of DEM along the eight azimuth directions in north-central Crete. Ten morphometric classes were isolated using iterative self-organising data analysis techniques (ISODATA) unsupervised classification. A quick estimation of the spatial distribution of similar morphologic units was therefore provided by this approach. The resultant units were then superimposed on land cover types in the study area, where the relative association between the morphologic units and dominant land cover types were determined.

Abbate et al. (2006) adopted the same method described by Parcharidis et al. (2001) in examining the relation between morphological setting and vegetation covers in a medium relief landscape in Central Italy. The results established mutual relations between vegetation types and land cover units through the assessment of corresponding analysis between the results of the classifications of land surface and vegetation cover. Camiz, Papgeorgiou, Poscolieri and Parcharidis (2013) used the same method in landform classification to examine correlation between landforms and ground deformation at Nisyros volcano in Greece.

Several other studies have been carried out in relation to topographic parameters and vegetation. Elumnoh and Shrestha (2000) reviewed many studies (Jones, Settle \& Whyatt, 1998; Janssen, Jaarsma \& van der Linder, 1990; Palacio-Pricto \& Luna-Gonzalez, 1996; Cibula \& Nyquist, 1987) on the integration of DEM data in land cover classification. Strahler, Logan and Bryant (1979) also used DEM data to describe terrain components in relation to spectral response, all making used of geomorphometric variables such as relief, slope, elevation, aspect and curvature. Civco (1989) was able to normalise Landsat TM data using DEM. Studies (for example, Howard \& Mitchel 1985) have shown the strong influence of aspect on vegetation distribution in temperate regions. However, the use of SRTM-3 DEM in achieving this has not been demonstrated in literature, particularly for the tropical environment. A very recent study (Efiong, Eze, Digha \& Asouzu, 2015) has however parameterised the land surface of a mountain region in the humid tropical environment using the SRTM-3 DEM, but no relationship of the land surface parameters to vegetation cover were made by the authors. This study therefore bridges this gap.

2. Conceptual framework

A strong relationship between soil and topography (relief) has been established since the work of Dokuchaev (1898), who first recognised the main driving factors of soil formation at a particular place to include, relief, climate, organism, parent materials and time. However, it was only in 1941 that Jenny (Jenny, 1941) was able to translate Dokuchaev observation into a mathematical model (soil catena) expressed as:

$\mathrm{S}=f(\mathrm{c}, \mathrm{o}, \mathrm{r}, \mathrm{p}, \mathrm{t})$

where,

$\mathrm{S}=$ soil variable

$\mathrm{c}=$ climate

$\mathrm{o}=$ organism

$\mathrm{r}=$ relief

$\mathrm{p}=$ parent material, and 
$\mathrm{t}=$ time.

This equation has however been extended (McBratney, Mendonsca-Santos \& Minasny, 2003) to include geographic position and the neighbouring soil properties (Dobos \& Hengl, 2009). The soil catena concept has also been extended to landform-vegetation studies. Hengl and MacMillan (2009) re-presented the model as:

$\mathrm{S}, \mathrm{V}=f(\mathrm{c}, \mathrm{o}, \mathrm{r}, \mathrm{p}, \mathrm{t})$,

Where,

$\mathrm{V}$, is vegetation.

While human activities and natural disasters play key roles in the distribution of vegetation cover over any region, the actual vegetation cover in a particular area may be as a result of the interactions between these different components. However, the effect of topography in controlling vegetation distribution is never in doubt (Abbate et al., 2006). The model of vegetation-relief (topography) relationship could therefore be of the form (Modified from Hengl \& MacMillan, 2009):

$\mathrm{V}=\mathrm{f}(\mathrm{r}, \mathrm{t})$

where,

$\mathrm{V}=$ vegetation

$r=$ relief

$\mathrm{t}=$ time

Hence, when all other factors (e.g. climate, parent materials, organisms etc.) are held constant, reliable vegetation maps could be produced from information on relief of appropriate accuracy.

\section{Method of Study}

\subsection{Study Area}

This study was conducted on the Obudu mountain region in Cross River State of Nigeria (Figure 1). The area is a prolongation of the Cameroon Mountain into the Cross River plains (Ekwueme \& Kröner, 2006; Efiong, 2011; Amuyou, Eze, Essoka, Efiong \& Egbai, 2013). The area has a rugged topography with steep valleys, highlands and plateau. It extends over $4590 \mathrm{~km}^{2}$ between latitudes $6^{\circ} 00^{\prime} \mathrm{N}$ and $6^{\circ} 45^{\prime} \mathrm{N}$, and longitudes $8^{\circ} 40^{\prime} \mathrm{E}$ and $9^{\circ} 30^{\prime} \mathrm{E}$ (Edet \& Okereke, 2005). Elevation ranges between $150 \mathrm{~m}$ and $1600 \mathrm{~m}$ above the local topography which is over $200 \mathrm{~m}$ above mean sea level. The plateau has an altitude of $1716 \mathrm{~m}$ above sea level (Roderkirchen, 2002).

The study area encompasses tropical rainforest, montane and grassland ecosystems with many endemic species of flora and fauna (Rodenkirchen, 2002). It should be noted here that this is one of the two places in Nigeria with significant montane forest, the other being the Mambilla plateau. However, there is an increasing rate of deforestation in the study area.

Part of the plateau has been developed into a ranch resort with the longest cable car in Africa. There are other tourist attractions within the resort itself which makes it a tourist haven. It also hosts a yearly international mountain race competition in November.

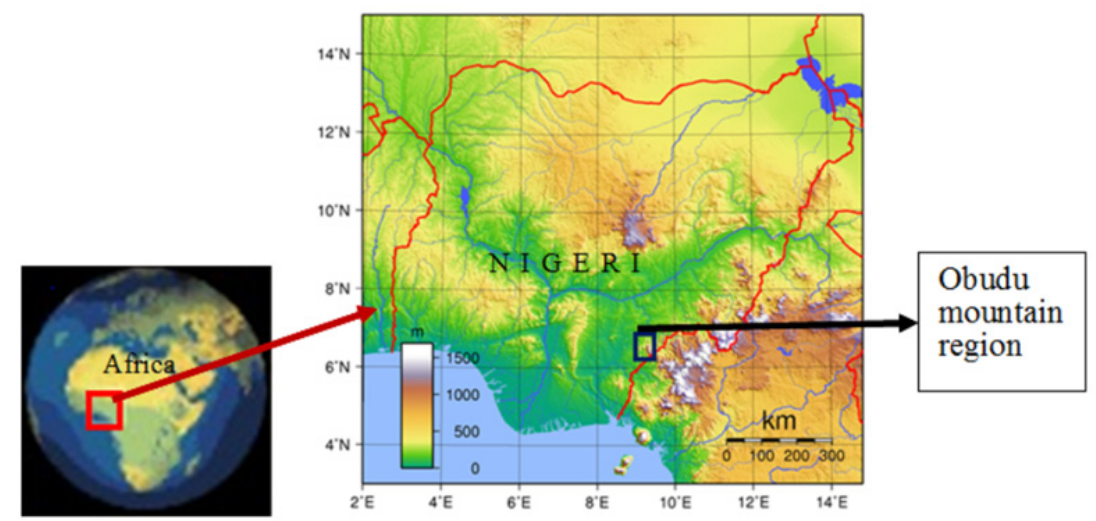

Figure 1.Topographic map of Nigeria showing the study area

Source: en.wikipedia.org 
Temperature at the ranch varies between $23^{\circ} \mathrm{C}$ and $32^{\circ} \mathrm{C}$ during the dry season and between 4 and $10^{\circ} \mathrm{C}$ in some months during the wet season. Average rainfall is $4200 \mathrm{~mm}$ per annum. With the above description, the area is therefore suitable for studies of this nature.

\subsection{Data}

SRTM-3 DEM and Landsat 8 satellite imagery served as the main data for this study. The SRTM-3 DEM was obtained from http://e4ft101.cr.usgs.gov/. The specific information regarding the tile that contains the area of interest (AOI) is presented in Table 1. This AOI is the same that was used by Efiong et al. (2015).

Landsat 8 data was obtained from the USGS Earth Resources Observation and Science Center (EROS) via http://glovis.usgs.gov/ free of charge. It has a total of 11 bands: operational land imager (OLI) multispectral bands 1-7 and 9 at 30m spatial resolution, OLI panchromatic band 8 at $15 \mathrm{~m}$ spatial resolution and the thermal infrared sensors (TIRS) bands 10 and 11 collected at $100 \mathrm{~m}$ but resampled to $30 \mathrm{~m}$ spatial resolution (http://landsat.usgs.gov/landsat8.php).

Table 1. SRTM DEM data characteristics

\begin{tabular}{|c|c|}
\hline Characteristic & Description \\
\hline Pixel size & $3 \operatorname{arc}$ second $(90 \times 90 \mathrm{~m})$ \\
\hline DEM output format & HGT, signed 16 bits, in units of vertical metres \\
\hline Special DN Values & N/A No voids in Version 3 \\
\hline Tile number & N06E009 \\
\hline $\begin{array}{l}\text { Area of interest (AOI) } \\
\text { (spatial extent) }\end{array}$ & Top: 714915; Left: 537645; Right: 543585; Bottom: 705195 \\
\hline Columns and rows & 66,108 \\
\hline Areal size & $57.7368 \mathrm{~km}^{2}$ \\
\hline Statistics & \\
\hline Pixel count & 7128 \\
\hline Minimum elevation & 688 \\
\hline Maximum elevation & 1767 \\
\hline Mean & 1322.595959596 \\
\hline Standard deviation & 225.27588196913 \\
\hline
\end{tabular}

However, bands 1-7 were used in this study since these are the bands where data were collected by the satellite sensor within the visible and near infrared regions of the electromagnetic spectrum. Basic characteristics of the data set of which the area of interest (AOI) was extracted from the stacked layers are shown in Table 2. This AOI has the same spatial extent with the SRTM-3 DEM.

Field work was done for 2 weeks in the month of June 2014 to allow for ground-truthing and collection of data for accuracy assessment. The field exercise involved the identification of the major vegetation cover, collection of elevation data of the land surface and location data for each of the identified vegetation cover type.

Table 2. Satellite image characteristics

\begin{tabular}{ll}
\hline Characteristics & Description \\
\hline Satellite & Landsat 8 \\
Date of acquisition & $07 / 01 / 2014$ \\
WRS-2 Paths/Rows & $187 / 56$ \\
Scene information & \\
ID & LC81870562014007LGN00 \\
Quality & 9 Product: OLI_TIRS_L1T \\
Data type & Unsigned 8-bit \\
Data format & TIFF \\
\hline Spatial extent & Top: 714915; Left: 537645; Right: 543585; Bottom: 705195 \\
Pixel size & 30 m x 30m \\
Projection & UTM, zone 32 \\
Spheroid & WGS 84 \\
Datum & WSG 84 \\
\hline
\end{tabular}




\subsection{Data Processing}

The generalised work-flow regarding the data analysis is presented in figure 2 and discussed in subsequent section.

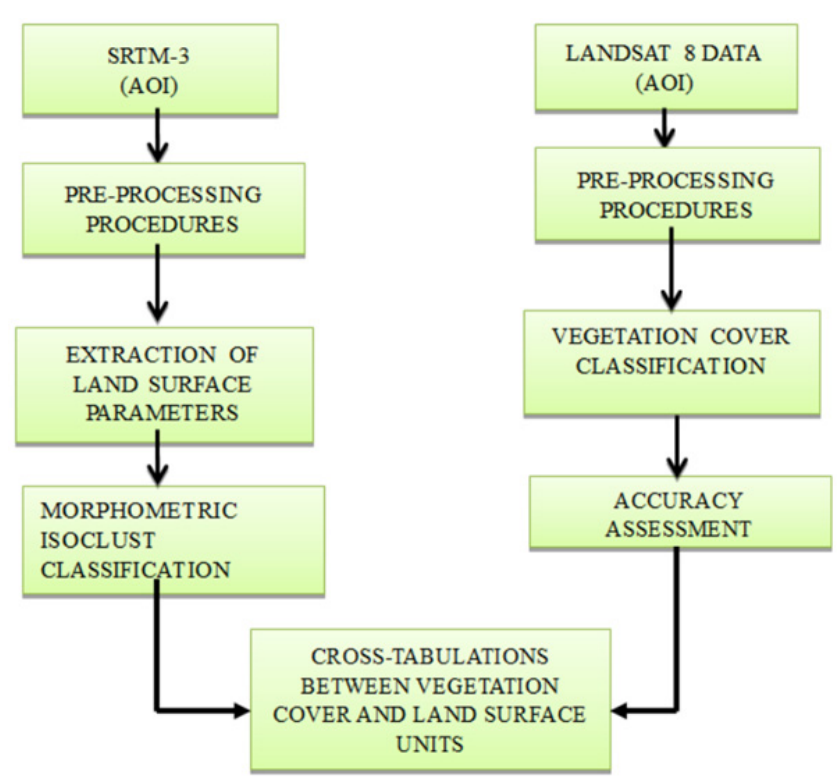

Figure 2. Generalised work-flow

For this study, care was taken in obtaining SRTM data that had been pre-processed to remove voids in the midst of so many versions of the product on the internet. The area AOI was then extracted from the entire tile. The data was re-projected to a projected coordinate system - UTM, zone $32 \mathrm{~N}$ with WGS 84 spheroid/datum. It was not possible to filter forest from the SRTM as data on forest height were not available.

Landsat data were also pre-processed before subsequent analysis were performed on it. First, the data were downloaded in bands and stacked. The area of interest (AOI) was then sub-setted from the entire stacked scene. There was no need for mosiaking since the AOI did not overlap another path/row. Haze reduction was performed on the image to reduced the hazy appearance of the image to allow for good visual interpretation. The image was geometrically corerected.

\subsection{Data Analysis}

\subsubsection{Classification of Geomorphometric Units}

Both the first (slope and aspect) and second (profile and plan curvatures) derivatives of land surface were extracted from the DEM the simple 3 x 3 window which is dragged across the gridded DEM points to estimate the value of the centre pixel using the neigbouring pixel values (Olaya, 2009)

Slope and aspect was calculated using the very local values (D8: 2-points, 8-direction, maximum-slope), that is, the eight 'Queens's case' neighbours (Horn, 1981). Curvature (profile and plan) were derived using the technique of quadratice surface provided by Zevenbergen and Thorne (1987). The extracted land surface parameters were classified based on a modified Young (1972) angle classification of slopes (Efiong et al., 2015). Curvature, including profile and plan curvatures, were classified into 3 classes based on positive ( + ), negative )-) or zero (0) curvature.

Since the major intention of this study was to link vegetation cover to geomorphometric units, the extracted land surface paramters were stacked into an image which served as an input data for geomorphometric classification using an unsupervised ISOCLUST algorithm in 3 iterations with a minimum sample size of 30 pixels per class.

\subsubsection{Classification of Vegetation Cover}

Vegetation cover classification was done using the supervised approach based on the Maximum Likelihood algorithm on the already pre-processed Landsat data. The classifier was trained to identify four (4) spectral signatures of the major vegetation classes in the study area. Training samples allow for certain characteristics of the statistical nature of the vegetation cover types to be discriminated. For the algorithm that was adopted here, 
these samples allowed for the mean vector and variance-covariance matrix to be estimated for each class (Mather \& Koch, 2011). Since the validity of statistical estimates from training samples depend on the size and how representative the sample is (Mather \& Koch, 2011), a total of 120 training samples (30 for each class) was selected from every part of the satellite image. The identification of the classes of these samples was aided by the field data, spectral profiles and visual interpretation of the image. A signature file of these samples was generated and saved in the computer memory and was later used in the supervised classification.

Accuracy of the classified map was then assessed using the confusion matrix. The algorithm for the determination of accuracy of classification of $k \times k$ confusion matrix has been dicussed in literature (see Mather \& Koch, 2011). In adopting this method, Erdas Imagine 2013 provided the necessary platform for the assessment. Figure 3 is the Erdas Imagine main viewer and the accuracy assessment viewer showing the classified map, class and reference data, together with the eastings and northings.

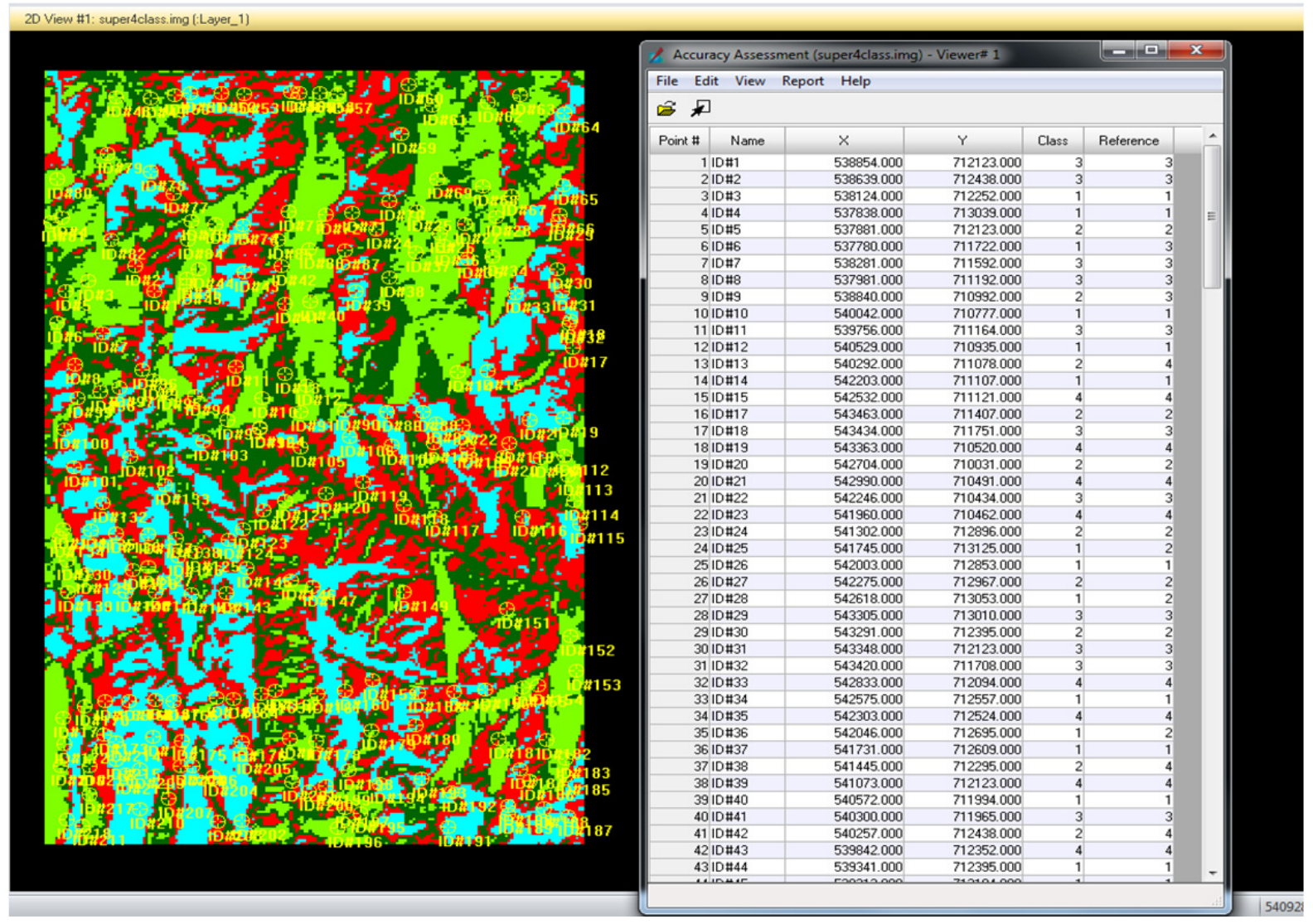

Figure 3. Erdas Imagine and accuracy assessment viewers

The kappa coeffiecient was used to summarised the information provided by the contingency matrix in statistical terms (Bishop, Fienberg \& Holland, 1975). Kappa coefficient is literally computed based on the formula:

$$
K=\frac{N \sum_{i}^{k} x-\sum_{i=1}^{k} x_{i}+x+i}{N-\sum_{i=1}^{k} n_{i}+x+i}
$$

where $\quad K=$ kappa coefficient

$k=$ number of classes

$\mathrm{N}=$ number of reference data samples

$\sum_{i}^{k} x=\quad$ sum of the diagonal entries of the confusion matrix

$\sum_{i=1}^{k} x_{i}+x+i=$ sum of the row and column marginal totals

Kappa's coefficient was interpreted based on the standard proposed by Landis and Koch (1977) (Table 3). See also Sim and Wright (2005). 
Table 3. Standard for the interpretation of kappa coefficient

Source: Landis \& Koch (1977)

\begin{tabular}{ll}
\hline Kappa coefficient & Interpretation \\
\hline$\leq \mathbf{0}$ & Poor \\
$\mathbf{0 . 0 1}-\mathbf{0 . 2 0}$ & Slight \\
$\mathbf{0 . 2 1}-\mathbf{0 . 4 0}$ & Fair \\
$\mathbf{0 . 4 1}-\mathbf{0 . 6 0}$ & Moderate \\
$\mathbf{0 . 6 1}-\mathbf{0 . 8 0}$ & Substantial \\
$\mathbf{2 0 . 8 0}$ & Almost perfect \\
\hline
\end{tabular}

\subsubsection{Statistical Analysis}

To allow for a grid-based statistical analysis between the geomorphometric units and vegetation cover distribution, the vegetation map was resampled from $30 \times 30 \mathrm{~m}$ cell size, to $90 \times 90 \mathrm{~m}$ using the bilinear interpolation method. Since vegeation data are categorical (nominal scale), landform parameters was also scaled down to nominal structure. Such uniformity allows for statistical calculation of correlations between the variables (Höersch, 2003).

There are various grid-based statistics, However, the Crosstab was used in this study. A standard Crosstab allows comparison to be made between two classified images and basically done by the use of Chi-square tests (de Smith, Goodchild \& Longley, 2009). Results of cross tabulations are often shown in contingency tables (Abbate et al., 2006; Adediran et al., 2004; Cavalli, Fussili, Pascuici, Pignatti \& Poscolieri, 2003; Höersch et al., 2002). Contingency tables are used to compare actual distributions with theoritical ones by means of chi-sqaure $\left(x^{2}\right)$ tests. Chi-Square statistic was computed based on the form:

$$
x^{2}=\sum \frac{(O-E)^{2}}{E}
$$

Where,

$$
\begin{aligned}
& \mathrm{O}=\text { Observed frequency } \\
& \mathrm{E}=\text { Expected frequency }
\end{aligned}
$$

To indicate independence between land surface (geomorphometric) and vegetation cover maps, the chi-sqauare value should be low. Moreover, $p$ should be close to 1, to indicate that the two images are likely similar. Further, two indices of overall (global) similarity (Kappa Index of Agreement and Cramer's V Index), which also are measures of correlation were used to establish the degree of similarity between the two images.

The Kappa Index of Agreement (KIA) is given as:

$$
k=\frac{O-E}{1-E}
$$

The Cramer's V Index is given as:

$$
v=\sqrt{\frac{1}{T} \frac{x^{2}}{\min \{(M-1),(N-1)\}}}
$$

where,

$\mathrm{Mx} \mathrm{N}$ is an array of the source table

These two indices are interpretated in the same way, having typical range of values between 0 and 1; where 1 indicates perfect agreement and 0 indicate chance agreement.

\section{Results}

The results of the unsupervised ISOCLUST classification of the land surface of the AOI in the Obudu mountainous region is shown in figure 4. From this map, it is clear that 9 land surface clusters were segregated and represented by distinct colours to aid interpretation. The areal coverage of the land surface clusters are presented in Table 4. Cluster 1 has the highest areal coverage of $8.8695 \mathrm{~km}^{2}$ while cluster 9 has the least areal coverage of $2.9970 \mathrm{~km}^{2}$. 
Figure 5 shows the map of supervised classification of the four dominant vegetation cover types in the Obudu mountain region. This was obtained from the Landsat data with spatial resolution of $30 \mathrm{~m}$. The dominant vegetation cover types are forest, scattered trees with shrubs, grasses with shrubs and bare surface / settlements. The classified map was resampled to a spatial resolution of $90 \mathrm{~m}$ (Figure 6) to allow for grid-based statistical analysis with the land surface map.

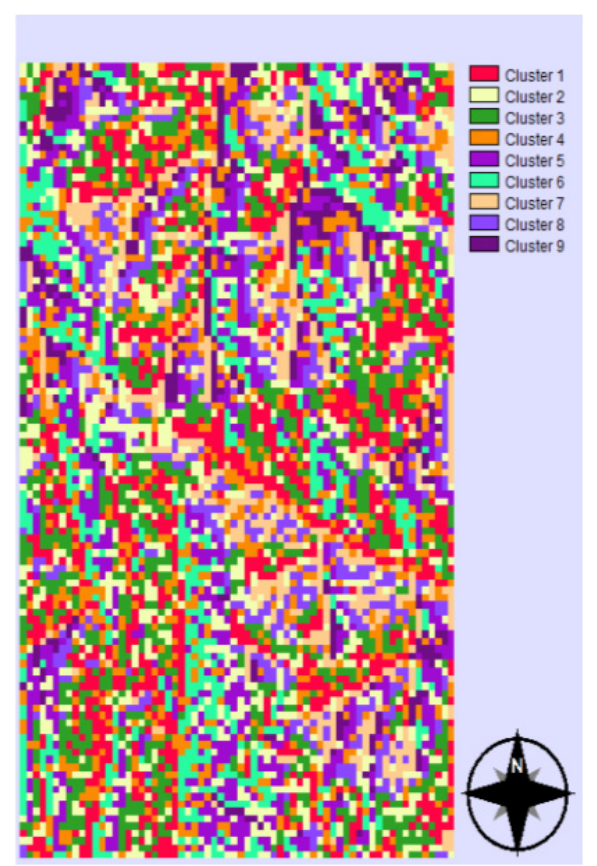

Figure 4. Nine clusters of land surface units

Table 4. Areal coverage of land surface clusters

\begin{tabular}{lll}
\hline Land surface cluster & $\begin{array}{l}\text { No. of pixels } \\
(\mathbf{s i z e}=\mathbf{9 0 m})\end{array}$ & Areal coverage $\left.\mathbf{( k m}^{\mathbf{2}}\right)$ \\
\hline 1 & 1095 & 8.8695 \\
2 & 1048 & 8.4888 \\
3 & 986 & 7.9866 \\
4 & 921 & 7.4601 \\
5 & 898 & 7.2738 \\
6 & 636 & 5.1516 \\
7 & 611 & 4.9491 \\
8 & 563 & 4.5603 \\
9 & 370 & 2.9970 \\
\hline Total & 7128 & 57.7368 \\
\hline
\end{tabular}




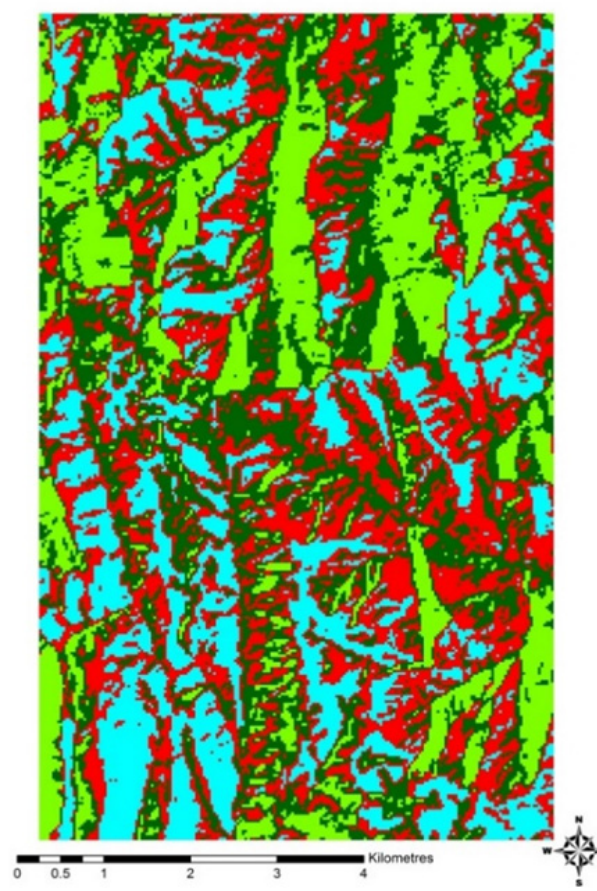

Legend

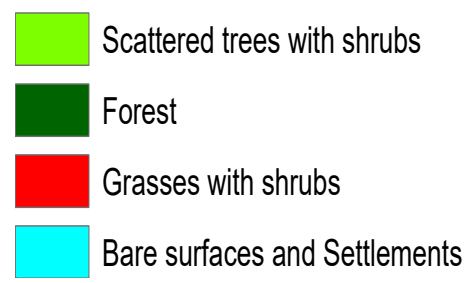

Figure 5. Vegetation cover map based on $30 \mathrm{~m}$ resolution cover map

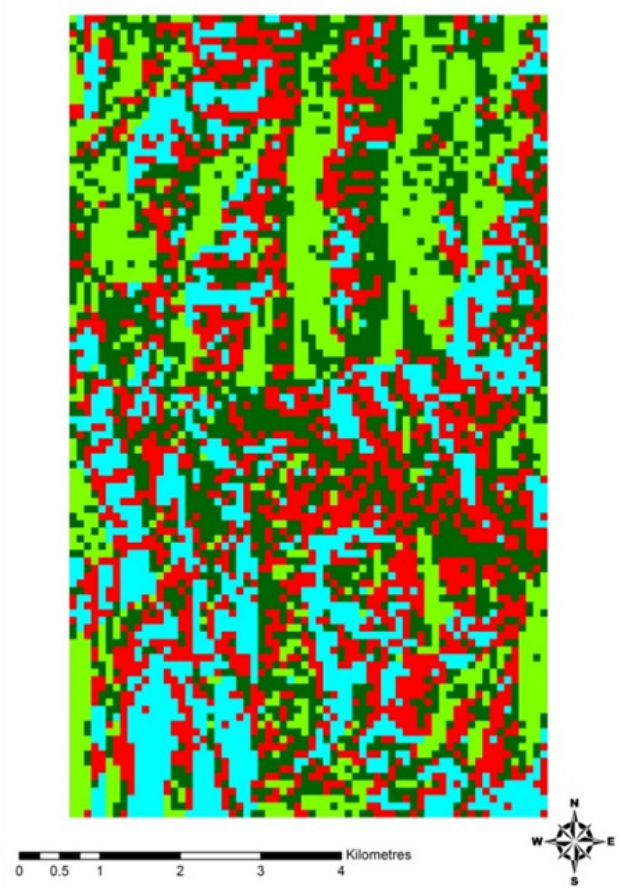

Legend

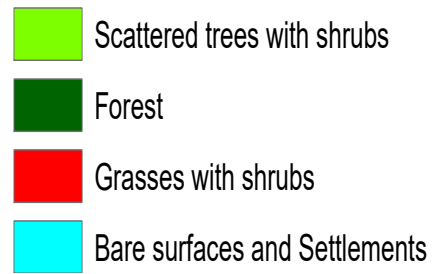

Figure 6. Resampled (90m resolution) vegetation

The overall accuracy of the classification of vegetation cover is $81.00 \%$ with an overall Kappa statistics of 0.75 The Kappa statistics is interpreted as being substantial (Table 5). The result of the vegetation classification reveals that canopy forest is the most dominant of the four types with total areal coverage and percentage distribution of $16.8075 \mathrm{~km}^{2}$ and 29.11 per cent while bare surface and settlements has the least with $12.1986 \mathrm{~km}^{2}$ (21.13 per cent) Table 6 \& Figure 7).

Table 5. Vegetation classification accuracy report

a. Error matrix

\begin{tabular}{|c|c|c|c|c|c|c|}
\hline Classified Data & $\begin{array}{l}\text { Unclassi-fie } \\
\text { d }\end{array}$ & $\begin{array}{l}\text { Scattered trees } \\
\text { with shrubs }\end{array}$ & Forest & $\begin{array}{l}\text { Grasses } \\
\text { with shrubs }\end{array}$ & $\begin{array}{l}\text { Bare surfaces } \\
\text { and settlement }\end{array}$ & $\begin{array}{l}\text { Total } \\
\text { Row }\end{array}$ \\
\hline Unclassified & $\mathbf{0}$ & 3 & 3 & 2 & 0 & 8 \\
\hline $\begin{array}{l}\text { Scattered trees with } \\
\text { shrubs }\end{array}$ & 0 & 43 & 5 & 2 & 2 & 52 \\
\hline Forest & 0 & 4 & 41 & 8 & 5 & 58 \\
\hline Grasses with shrubs & 0 & 0 & 3 & 52 & 0 & 55 \\
\hline $\begin{array}{l}\text { Bare surfaces and } \\
\text { settlement }\end{array}$ & 0 & 0 & 0 & 5 & 43 & 48 \\
\hline Column Total & 0 & 50 & 52 & 69 & 50 & 221 \\
\hline
\end{tabular}


b. Accuracy totals

\begin{tabular}{llllll}
\hline Class name & $\begin{array}{l}\text { Reference } \\
\text { totals }\end{array}$ & $\begin{array}{l}\text { Classified } \\
\text { totals }\end{array}$ & $\begin{array}{l}\text { Number } \\
\text { correct }\end{array}$ & $\begin{array}{l}\text { Producer's } \\
\text { accuracy }\end{array}$ & $\begin{array}{l}\text { User's } \\
\text { accuracy }\end{array}$ \\
\hline $\begin{array}{l}\text { Unclassified } \\
\begin{array}{l}\text { Scattered trees } \\
\text { shrubs }\end{array}\end{array}$ & 0 & 8 & 0 & & \\
$\begin{array}{l}\text { Forest } \\
\text { Grasses with shrubs }\end{array}$ & 50 & 52 & 43 & $86.00 \%$ & $82.69 \%$ \\
$\begin{array}{l}\text { Bare surfaces and } \\
\text { settlement }\end{array}$ & 59 & 58 & 41 & $78.85 \%$ & $70.69 \%$ \\
$\begin{array}{l}\text { Totals } \\
\text { Overall classification accuracy }\end{array}$ & 50 & 52 & 43 & $75.36 \%$ & $94.55 \%$ \\
\hline
\end{tabular}

c. Kappa $\left(\mathrm{K}^{\wedge}\right)$ Statistics

\begin{tabular}{lc}
\hline \multicolumn{2}{l}{ Conditional Kappa for each Category } \\
\hline Class Name & Kappa \\
\hline Unclassified & 0.0000 \\
Scattered trees with shrubs & 0.7763 \\
\hline Forest & 0.6167 \\
Grasses with shrubs & 0.9207 \\
\hline Bare surfaces and settlement & 0.8654 \\
Overall Kappa Statistics & $\mathbf{0 . 7 4 9 3}$ \\
\hline
\end{tabular}

Table 6. Areal and percentage coverage of vegetation cover

\begin{tabular}{|c|c|c|c|}
\hline Vegetation cover type & $\begin{array}{l}\text { No. of pixels } \\
\text { covered }\end{array}$ & $\begin{array}{lll}\begin{array}{l}\text { Total } \\
\left(\mathbf{k m}^{2}\right)\end{array} & \text { areal coverage } \\
\end{array}$ & $\begin{array}{l}\text { \% of total area } \\
\text { covered }\end{array}$ \\
\hline Scattered tress with shrubs & 1513 & 12.2553 & 21.23 \\
\hline Forest & 2075 & 16.8075 & 29.11 \\
\hline Grasses with shrubs & 2034 & 16.4754 & 28.53 \\
\hline $\begin{array}{l}\text { Bare surfaces and } \\
\text { settlements }\end{array}$ & 1506 & 12.1986 & 21.13 \\
\hline Total & 7128 & 57.7368 & 100.00 \\
\hline
\end{tabular}

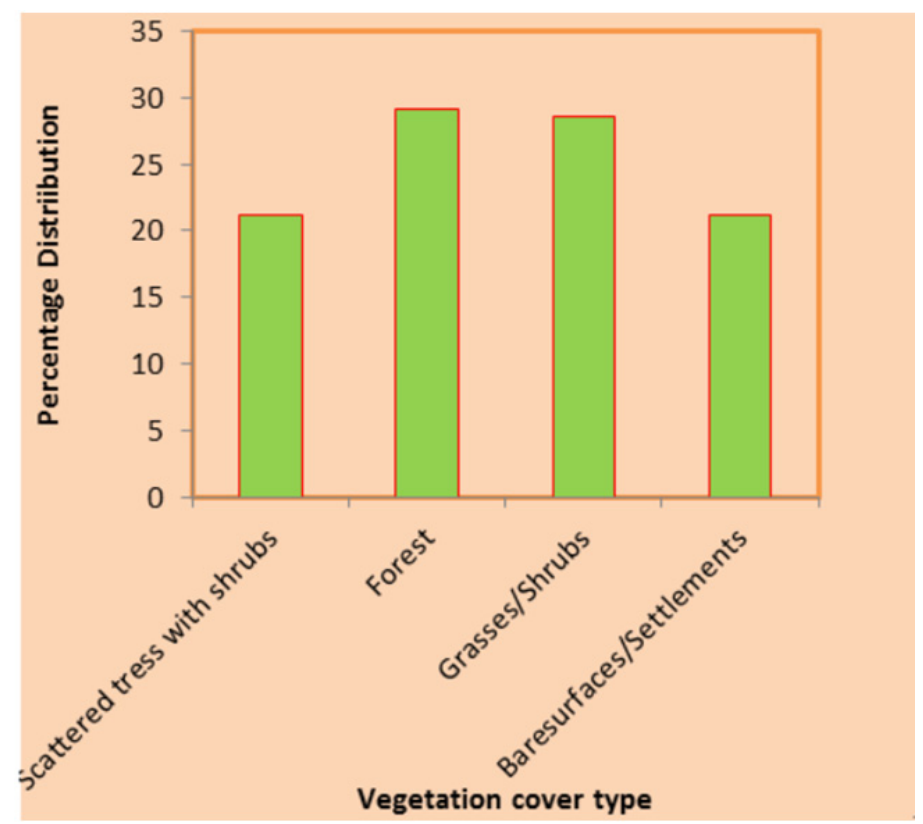

Figure 7. Percentage distribution of vegetation cover 
The result of the grid-based cross-tabulation for examining the relationship between land surface units and vegetation cover is presented in Tables 7 and 8 . Figure 8 is the map output. Table 7 shows the distribution of the vegetation cover types within the different land surface units. This actually shows the number of pixels for each of the classes in the land surface and vegetation cover maps. For instance, there are 238 pixel classified as grasses with shrubs within land surface unit 1 (concave slopes, facing E - SE - S directions), but 106 pixels classified as scattered tress with shrubs within the same land surface unit.

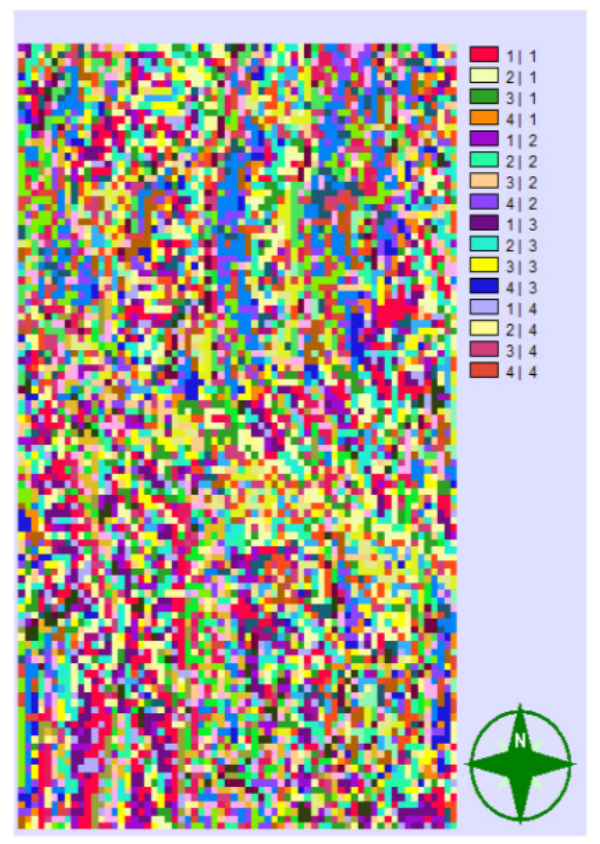

Figure 8. Map output of the cross-tabulation of vegetation cover over land surface units

Table 7. Distribution of vegetation cover over land surface units in terms of number of pixels

\begin{tabular}{|c|c|c|c|c|c|}
\hline \multirow{2}{*}{$\begin{array}{l}\text { Land surface } \\
\text { units }\end{array}$} & \multicolumn{4}{|c|}{ Vegetation distribution } & \multirow[b]{2}{*}{ Total } \\
\hline & $\begin{array}{l}\text { Scattered trees with } \\
\text { shrubs }\end{array}$ & Forest & $\begin{array}{l}\text { Grasses } \quad \text { with } \\
\text { shrubs }\end{array}$ & $\begin{array}{l}\text { Bare surfaces and } \\
\text { settlements }\end{array}$ & \\
\hline 1 & 106 & 246 & 238 & 505 & 1095 \\
\hline 2 & 258 & 278 & 294 & 218 & 1048 \\
\hline 3 & 162 & 226 & 322 & 276 & 986 \\
\hline 4 & 178 & 314 & 233 & 196 & 921 \\
\hline 5 & 431 & 210 & 172 & 85 & 898 \\
\hline 6 & 172 & 223 & 143 & 98 & 636 \\
\hline 7 & 76 & 146 & 277 & 112 & 611 \\
\hline 8 & 145 & 163 & 168 & 87 & 563 \\
\hline 9 & 75 & 146 & 111 & 38 & 370 \\
\hline Total & 1603 & 1952 & 1958 & 1615 & 7128 \\
\hline
\end{tabular}

Table 8 is the proportional distribution of each vegetation cover type in relation to the land surface units The overall measure of the difference resulted in a chi-square value of $1.91541(\mathrm{df}=24, p>0.05)$. This means that there is no significant difference between the geomorphometric units (land surface) and the vegetation cover at the 0.05 confidence level. The results of overall (global) similarity between the two maps, which provides a form of correlation measure (de Smith et al., 2009) determined as Cramer's V and Kappa Index of Agreement (KIA) are 0.61 and 0.53 respectively. These are also in support of the fact that the two maps are similar. 
Table 8. Proportional distribution of vegetation in relation to land surface units

\begin{tabular}{|c|c|c|c|c|c|c|}
\hline \multirow{2}{*}{$\begin{array}{l}\text { Land } \\
\text { units }\end{array}$} & \multirow[t]{2}{*}{ surface } & \multicolumn{5}{|l|}{ Vegetation distribution } \\
\hline & & $\begin{array}{l}\text { Scattered trees with } \\
\text { shrubs }\end{array}$ & Forest & $\begin{array}{l}\text { Grasses with } \\
\text { shrubs }\end{array}$ & $\begin{array}{l}\text { Bare surfaces and } \\
\text { settlements }\end{array}$ & Total \\
\hline 1 & & 0.0149 & 0.0345 & 0.0334 & 0.0708 & 0.1536 \\
\hline 2 & & 0.0362 & 0.0390 & 0.0413 & 0.0306 & 0.1470 \\
\hline 3 & & 0.0226 & 0.0317 & 0.0452 & 0.0387 & 0.1383 \\
\hline 4 & & 0.0250 & 0.0441 & 0.0327 & 0.0275 & 0.1292 \\
\hline 5 & & 0.0605 & 0.0295 & 0.0241 & 0.0119 & 0.1260 \\
\hline 6 & & 0.0241 & 0.0313 & 0.0201 & 0.0137 & 0.0892 \\
\hline 7 & & 0.0107 & 0.0205 & 0.0389 & 0.0157 & 0.0857 \\
\hline 8 & & 0.0203 & 0.0229 & 0.0236 & 0.0122 & 0.0790 \\
\hline 9 & & 0.0105 & 0.0205 & 0.0156 & 0.0053 & 0.0519 \\
\hline Total & & 0.2248 & 0.2740 & 0.2748 & 0.2264 & 1.0000 \\
\hline
\end{tabular}

A standardisation of the results in Table 7 in terms of percentage occurrence of each vegetation covers across the land surface units yielded Table 9. The dominant vegetation covers over land surface units are the bold-faced underlined digits.

The criterion for inclusion as dominant vegetation cover within any land surface unit is $33.33 \%$ which is one-third of the total vegetation coverage (Udofia, 2011). It is now clearer from Table 9 that scattered trees with shrubs are more prominent in land surface units 5 (convex slopes, facing W - SW and NW directions), forest is typical of land surface units 4, 6 and 9, grasses with shrubs are in 7 (concave slopes, facing NE - N directions) while bare surfaces and settlements are typical of land surface unit 1 (concave slopes, facing E - SE - S directions) (See also Table 10).

Table 9. Percentage distribution of vegetation in relation to land surface units

\begin{tabular}{lllllllll}
\hline $\begin{array}{l}\text { Land surface } \\
\text { units }\end{array}$ & \multicolumn{9}{l}{ Vegetation distribution (per cent) } & & $\begin{array}{l}\text { Slope direction } \\
\text { (Aspect }\end{array}$ \\
\cline { 2 - 7 } & $\begin{array}{l}\text { Scattered } \\
\text { with shrubs }\end{array}$ & trees & Forest & $\begin{array}{l}\text { Grasses } \\
\text { shrubs }\end{array}$ & with & $\begin{array}{l}\text { Bare surfaces and } \\
\text { settlements }\end{array}$ & Total & \\
$\mathbf{1}$ & 9.68 & 22.47 & 21.69 & $\underline{\mathbf{4 6 . 1 6}}$ & 100 & E - SE - S \\
$\mathbf{2}$ & 24.62 & 26.53 & 28.05 & 20.80 & 100 & E - NE, W \\
$\mathbf{3}$ & 16.43 & 22.92 & 32.66 & 27.99 & 100 & E - SE - S \\
$\mathbf{4}$ & 19.33 & $\underline{\mathbf{3 4 . 0 5}}$ & 25.34 & 21.28 & 100 & E - NE, W \\
$\mathbf{5}$ & $\underline{\mathbf{4 7 . 9 7}}$ & 23.41 & 19.15 & 9.47 & 100 & W -SW - NW \\
$\mathbf{6}$ & 27.05 & $\underline{\mathbf{3 5 . 0 6}}$ & 22.48 & 15.41 & 100 & W - SW \\
$\mathbf{7}$ & 12.44 & 23.88 & $\underline{\mathbf{4 5 . 3 5}}$ & 18.33 & 100 & NE - N \\
$\mathbf{8}$ & 25.76 & 28.95 & 29.84 & 15.45 & 100 & NE - N \\
$\mathbf{9}$ & 20.27 & $\underline{\mathbf{3 9 . 4 6}}$ & 30.00 & 10.27 & 100 & NW - N \\
\hline
\end{tabular}


Table 10. Description of land surface units in Obudu mountain region

\begin{tabular}{|c|c|c|c|c|}
\hline $\begin{array}{l}\text { Clusters } \\
\text { of land } \\
\text { surface } \\
\text { units }\end{array}$ & $\begin{array}{l}\text { Slope } \\
\text { direction } \\
\text { (Aspect) }\end{array}$ & $\begin{array}{l}\text { Plan } \\
\text { curvature } \\
\text { description }\end{array}$ & $\begin{array}{l}\text { Profile } \\
\text { curvature } \\
\text { description }\end{array}$ & General description of the land surface \\
\hline 1 & $E-S E-S$ & Concave slopes & Concave slopes & Concave slopes, facing E - SE - S directions \\
\hline 2 & E - NE, W & Concave slopes & Convex slopes & Concave - convex slopes, facing $\mathrm{E}$ - NE and $\mathrm{W}$ directions \\
\hline 3 & $E-S E-S$ & Convex slopes & Convex slopes & Convex slopes, facing $\mathrm{E}$ - SE - s directions \\
\hline 4 & E - NE, W & Convex slopes & Concave slopes & Convex - concave slopes, facing $\mathrm{E}-\mathrm{NE}$ and $\mathrm{W}$ directions \\
\hline 5 & W -SW - NW & Convex slopes & Convex slopes & Convex slopes, facing $\mathrm{W}-\mathrm{SW}$ and $\mathrm{NW}$ directions \\
\hline 6 & W - SW & Concave slopes & Concave slopes & Concave slopes, facing $\mathrm{W}$ - SW directions \\
\hline 7 & $\mathrm{NE}-\mathrm{N}$ & Concave slopes & Concave slopes & Concave slopes, facing NE - $\mathrm{N}$ directions \\
\hline 8 & $\mathrm{NE}-\mathrm{N}$ & Convex slopes & Convex slopes & Convex slopes, facing NE - N directions \\
\hline 9 & $\mathrm{NW}-\mathrm{N}$ & Concave slopes & Concave slopes & Concave slopes, facing NW - N directions \\
\hline
\end{tabular}

Source: Efiong et al. (2015)

\section{Discussion}

The main aim of this study was to relate vegetation cover to land surface units. In the context of spatial analysis, the result of the chi-square test therefore means that there is no significant difference between the land surface units and vegetation cover in the Obudu mountain region. Hence, the two maps (land surface units and vegetation cover) are similar. de Smith et al. (2009) argues that Cramer's V and Kappa Index of Agreement (KIA) provide forms of correlation for grid-based spatial analysis. Where images are similar (showing significant relationships), it is expected that these two indices should be 1 or closer to 1 (de Smith et al., 2009). In the present study, the two indices have values of 0.61 and 0.53 for Cramer's V and Kappa Index of Agreement (KIA) between the two maps respectively. Hence, the two images are similar.

While the results in Tables 7 and 8 do not present a good picture of the vegetation distribution over the land surface units, since they are based on number of pixels, the standardised results in Table 9 gives a better picture of the percentage occurrence of vegetation covers over the land surface units. Several studies including Cavalli et al. (2003) and Abatte et al. (2006) had adopted the standardisation approach to improve the interpretation of their results. In adopting this approach in the present study, each corresponding absolute representative number of pixels was standardised with respect to the total number of pixels of the land surface unit that is considered. The results of this standardisation (Table 9) present a clearer picture of the cross-tabulation, yet there are no sharp boundaries. The non-existence of sharp boundaries is also common in literature. For example, Table 11 presents the results in a similar study by Adediran et al. (2004).

Table 11. Spatial distribution and relationship between the geomorphological units and percent landcover/land use types (Adediran et al., 2004:368)

\begin{tabular}{|c|c|c|c|c|c|c|c|c|c|c|}
\hline \multirow[t]{2}{*}{ Landcover types } & \multicolumn{10}{|c|}{ Geomorphological units } \\
\hline & 1 & 2 & 3 & 4 & 5 & 6 & 7 & 8 & 9 & 10 \\
\hline Bare rocks & 0.01 & 0.00 & 0.22 & 0.00 & 0.03 & 0.00 & 0.01 & 0.05 & 0.00 & 0.00 \\
\hline Sclerophyllous vegetations & 0.46 & 0.98 & 0.45 & 0.92 & 0.58 & 0.45 & 0.22 & 0.27 & 0.36 & 0.39 \\
\hline Sparsely vegetated areas & 10.19 & 15.82 & 9.90 & 9.70 & 7.31 & 24.58 & 5.71 & 9.13 & 16.03 & 21.05 \\
\hline Artificial surfaces & 0.08 & 0.06 & 0.15 & 0.03 & 0.01 & 0.00 & 0.00 & 0.02 & 0.09 & 0.00 \\
\hline Transitional woodland/shrub & 5.75 & 5.00 & 7.26 & 7.11 & 13.25 & 11.34 & 18.97 & 12.03 & 9.83 & 10.71 \\
\hline Natural grassland & 17.19 & 17.45 & 17.45 & 17.68 & 21.70 & 25.21 & 20.56 & 19.13 & 19.13 & 17.01 \\
\hline Mixed forest & 0.45 & 0.41 & 0.20 & 0.29 & 0.43 & 0.24 & 1.12 & 0.47 & 2.34 & 1.90 \\
\hline Olive & 47.45 & 43.05 & 48.61 & 49.19 & 41.27 & 27.84 & 33.34 & 38.69 & 37.35 & 38.94 \\
\hline Complex cultivation pattems & 8.10 & 10.08 & 5.97 & 7.44 & 4.11 & 3.32 & 2.11 & 3.33 & 3.98 & 2.40 \\
\hline Broad leaves forest & 0.45 & 0.97 & 0.93 & 1.49 & 1.25 & 0.71 & 0.47 & 1.07 & 0.39 & 0.27 \\
\hline Coniferous forest & 9.82 & 6.16 & 8.84 & 6.14 & 10.06 & 6.29 & 17.46 & 15.79 & 10.47 & 7.26 \\
\hline
\end{tabular}

By way of interpreting this results Adediran et al. (2004:368) writes:

"Specifically, (the table) reveals a close spatial association between steeply sloping areas facing NE and sparsely 
vegetated areas, with this land cover accounting for $24.6 \%$ of morphometric unit total coverage. A similar pattern could also be discerned between coniferous forest and steep/average sloping areas facing west, where coniferous forest accounted for $15.8 \%$."

From this standpoint, it has also been demonstrated in this study that there are close spatial associations between some land surface units and vegetation cover; hence some vegetation classes are more typical of particular land surface units than others. For example, scattered trees with shrubs are more typical of land surface unit 5 than in other units while grasses and shrubs are more typical of land surface unit 7 . Similarly, forest cover tends to be typical distributed on land surface units 4, 6 and 9 while bare surfaces and settlements are typically located within land surface unit 1.

Moreover, there is an apparent dominance of forest in concave slopes (land surface units 4,6 and 9) than in other land surface units. Garcia-Aguirre, Ortiz, Zamorano \& Reyes (2007) noted the close relationship between slope geometry and fluvial dynamics of overland flow and infiltration. While convex slopes support overland flow, concave slopes on the other hand promote infiltration. It is therefore natural to have higher vegetation density on concave slopes than is found on convex slopes, particularly in the humid tropics where concave slopes reduces fluvial erosion and favours the availability of water for forest growth. On the other hand, scattered trees with shrubs tend to dominate convex slopes (land surface unit 4) where there are less infiltration and more fluvial erosion. The findings of this study agree with those of (Garcia-Aguirre et al., 2007).

This study has shown that some relationships exist between vegetation cover and land surface units in the study area. Hence, classification of land surface units using SRTM-3 can provide a reasonable understanding of spatial distribution vegetation cover of mountainous areas, irrespective of it spatial resolution of $90 \mathrm{~m}$. However, application of the findings of this study to other areas should be done with care as entirely different results could be obtained in areas with different profile curvature and plan curvature values. In the present case, the study area is more of a plateau (Efiong et al., 2015).

Again, there are also a number of conceptual problems associated with the use of DEMs (see Fisher, 1993; Wood, 1996; Tate \& Wood, 2001). Whilst the issue of scale dependency is not a consideration in this study because the study's interest from the outset has been on the use of the SRTM-3 product which has 90m spatial resolution, it should be noted that the elevation data in SRTM is rather a representation of a digital surface model (DSM) and not a bare-earth model. This implies that built-up areas and dense forest covers are part of the DEM (Nelson, Reuter \& Gessler, 2009). This can increase the uncertainty in the results of some kind of analysis done using the SRTM-3 DEM.

The findings of this study can be improved upon firstly, by normalising for topographic effect in the Landsat data for vegetation classification as this could improve the accuracy of the classification. Secondly, the uncertainty of the final outcome of the study could be further reduced if forest covers are filtered from the SRTM-DEM before subsequent extraction of land surface parameters. It is suggested that Wood (1996) algorithm and the self-organizing map as adopted by Eshani and Quiel (2008) could be used in characterising land surface using the SRTM-3 DEM and the results compared with the findings of the present study.

\section{Conclusion}

The SRTM-3 and Landsat data have provided reasonable understanding of the relationship between land surface and vegetation cover in the Obudu mountain region. The result of the study has shown significant relationship between land surface and vegetation cover in mountainous regions. It is concluded that SRTM-3 DEM can be used to predict vegetation cover in mountainous regions where other data are lacking. However, more studies involving the use of the SRTM publicly available DEM should be conducted on other mountainous areas so as to arrive at a more general relationship. Results from such studies could be used to validate the findings of the present study. Again, the present study could be extended to include field validation of the land surface units to reduce the level of uncertainty in the results.

The study has therefore provided new insights into the use of SRTM-3 in vegetation mapping of mountainous areas which should provoke further research. Moreover, this is the first attempt at characterising the land surface and developing a detailed vegetation map of the major vegetation cover types in the Obudu mountain region. The findings of this study are therefore of immense benefits to land resource managers and forestry agencies. For instance, the cost of reforesting a DEM cell can be estimated using information on slope. Moreover, this study would contribute in solving one of the greatest challenges of today's world which is the conservation of earth's resources for sustainable development. Hence, this study has implications for research, theory and practice. 


\section{References}

Abbate, G., Cavalli, R. M., Pascucci, S., Pignatti, A., \& Poscolieri, M. (2006). Relations between morphological settings and vegetation covers in a medium relief landscape of Central Italy. Annals of Geophysics, 49(1), $153-165$.

Adediran, A. O., Parcharidis, I., Poscolieri, M., \& Pavlopoulos, K. (2004). Computer-assisted discrimination of morphological units on north-central Crete (Greece) by applying multivariate statistics to local relief gradients. Geomorphology, 58, 357-370. http://dx.doi.org/10.1016/j.geomorph.2003.07.024

Amuyou, U. A., Eze, E. B., Essoka, P. A. Efiong. J., \& Egbai, O. O. (2013). Spatial variability of soil properties in Obudu mountain Region of Southeastern Nigeria. International Journal of Humanities and Social Sciences, 3(15), 145-149.

Bishop, Y. M., Fienberg, S. E., \& Holland, P. W. (1975). Discrete multivariate analysis: theory and practice. Cambridge: MIT Press.

Bolstad, P. V., Swank, W., \& Vose, J. (1998). Predicting Southern Appalachian over story vegetation with digital terrain data. Landscape Ecology, 13, 271-283. http://dx.doi.org/10.1023/A:1008060508762

Camiz, S., Papgeorgiou, E., Poscolieri, M., \& Parcharidis, I. (2013). Correlations between landforms and ground deformation at Nisyros volcano (Greece). Proc. ESA Living Planet Symposium 2013, Edinburg, UK, 9-13. September 2013.

Cavalli, R. M., Fusilli, L., Pascucci, S., Pignatti, S., \& Poscolieri, M. (2003). Relationships between morphological units and vegetation categories of Soratte Mount (Italy) as inferred by processing elevation and MIVIS hyperspectral data. In Benes, T. (Ed.), Geoinformation for European-wide Integration, 573-579. Rotterdam: Millpress.

Cibula, W. G., \& Nyquist, M. O. (1987). Use of topographic and climatological models in a geographical data base to improve Landsat MSS classification for Olympic National Park. Photogmmmetric Engineering and Remote Sensing, 53(1), 67-75.

Civco, D. L. (1989). Topographic normalization of Landsat thematic mapper digital imagery. Photogmmmetric Engineering and Remote Sensing, 55(9), 1303-1309.

de Smith, M. J., Goodchild, M. F., \& Longley, P. A. (2009). Geospatial analysis: A comprehensive guide to principles, techniques and software tools. Third edition. UK: Matador.

Dobos, E., \& Hengl, T (2009). Soil mapping applications. In Hengl, T and Reuter H, I (Eds.). Geomorphometry: Concepts, Software, Applications, (461-479). Oxford: Elsevier.

Dokuchaev, V. V. (1898). On soil zones in general, and on the vertical zones specifically. Selected Papers 1949, 3, 322-329.

Edet, A., \& Okereke, C. (2005). Hydrogeological and hydrochemical character of the regolith aquifer, northern Obudu Plateau, southern Nigeria. Hydrogeology Journal, 13, 391-415. http://dx.doi.org/10.1007/s10040-004-0358-9

Efiong, J. (2011). Effect of landuse on water discharge in humid regions: an example from southeastern Nigeria. Global Journal of Social Sciences, 10(1\&2), 53-61.

Efiong, J., Eze, E. B., Digha, O. N., \& Asouzu, O. E. (2015). A GIS-based land surface parameterisation of Obudu mountain region using SRTM-3 DEM. Journal of Basic and Applied Research International, 10(1), 34- 44.

Ehsani, A. H., \& Quiel, F. (2008). Geomorphometric feature analysis using morphometric parameterization and artificial neural network. Geomorphology, 99, 1-12. http://dx.doi.org/10.1016/j.geomorph.2007.10.002

Ekwueme, B. N., \& Kröner, A. (2006). Single zircon ages of migmatitic gneisses and granulites in the Obudu Plateau: Timing of granulite-facies metamorphism in southeastern Nigeria. Journal of African Earth Sciences, 44, 459-469 http://dx.doi.org/10.1016/j.jafrearsci.2005.11.013

Elumnoh, A., \& Shrestha, R. P. (2000). Application of DEM data to Landsat Image classification: Evaluation in a tropical wet-dry landscape of Thailand. Photogrammetric Engineering and Remote Sensing, 66(3), $297-$ 304.

Fisher, N. I. (1993). Statistical analysis of circular data. Cambridge: Cambridge University Press. http://dx.doi.org/10.1017/CBO9780511564345 
Florinsky, I, V., \& Kuryakova, G. A. (1996). Influence of topography on some vegetation cover properties. Catena, 27, 123-141. http://dx.doi.org/10.1016/0341-8162(96)00005-7

Garcia-Aguirre, M. C., Ortiz, M. A., Zamorano, J. J., \& Reyes, Y (2007). Vegetation and landform relationships at Ajusco volcano Mexico using a geographic information system (GIS), Forest Ecology and Management, 239, 1-12. http://dx.doi.org/10.1016/j.foreco.2006.10.031

Hengl, T., \& MacMillan, R. A. (2009). Geomorphometry- a key to landscape mapping and modelling. In Hengl, T and Reuter H, I (Eds.), Geomorphometry: Concepts, Software, Applications, (31-63). Oxford: Elsevier.

Höersch, B. (2003). Modelling the spatial distribution of montane and subalpine forests in the central Alps using digital elevation models. Ecological Modelling, 168, 267-282. http://dx.doi.org/10.1016/S0304-3800(03)00141-8

Höersch, B., Braun, G., \& Schmidt, U. (2002). Relations between landforms and vegetation in alpine regions of Wallis, Switzerland. A multiscale remote sensing and GIS approach. Computers, Environment and Urban Systems, 26, 113-139. http://dx.doi.org/10.1016/S0198-9715(01)00039-4

Horn, B. K. P. (1981). Hill shading and the reflectance map. Proceedings in IEEE, 69(1), 14-47. http://dx.doi.org/10.1109/PROC.1981.11918

Howard, J. A., \& Mitchel, C. W. (1985). Phyto-geomorphology. USA: John Wiley \& Sons, Inc.

Janssen, L. F., Jaarsma, J., \& van der Linder, E. (1990). Integrating topographic data with remote sensing for land-cover classification. Photogrammetric Engineering \& Remote Sensing, 56(11),1503- 1506.

Jenny, H. (1941). Factors of soil formation. New York: McGraw-Hill.

Jones, A. R., Settle, J. J., \& Wyatt, B. K. (1998). Use of digital terrain data in the interpretation of SPOT-1 HRV multispectral imagery. International Journal of Remote Sensing, 9(4), 669-682. http://dx.doi.org/10.1080/01431168808954885

Landis, J. R., \& Koch, G. G. (1977). The measurement of observer agreement for categorical data. Biometrics, 33, 159-174. http://dx.doi.org/10.2307/2529310

Langford, M., \& Bell, W. (1997). Land cover mapping in a tropical hillsides environment: a case study in the Cauca Region of Colombia. International Journal of Remote Sensing, 18(6), 1289-1306. http://dx.doi.org/10.1080/014311697218421

Lillesand, T. M., Kiefer, R. W., \& Chipman, J. W. (2008). Remote sensing and image interpretation (6th ed.). USA: John Wiley \& Sons, Inc

Mather, P. M., \& Koch, M. (2011). Computer processing of remotely-sensed images: an introduction (4th ed.). UK: Wiley-Blackwell. http://dx.doi.org/10.1002/9780470666517

McBratney, A. B., Mendonca Santos, M. L., \& Minasny, B. (2003). On digital soil mapping. Geoderma, 117(1-2), 3-5. http://dx.doi.org/10.1016/S0016-7061(03)00223-4

Nelson, A., Reuter, H. I., \& Gessler, P. (2009). DEM production methods and sources. In Hengl, T and Reuter H, I (Eds.), Geomorphometry: Concepts, Software, Applications, (65-85). Oxford: Elsevier.

Olaya, V. (2009). Basic land-surface parameters. In T. Hengl, \& H. I. Reuter (Eds.). Geomorphometry: Concepts, Software, Applications, (141-169). Oxford: Elsevier.

Palacio-Prieto, J. L., \& Luna-GonzAlez (1996). Improving spectral results in a GIS context. International Journal of Remote Sensing, 17(11), 2201-2209. http://dx.doi.org/10.1080/01431169608948766

Parcharidis, I., Pavlopoulos, A., \& Poscolieri, M. (2001). Geomorphometric analysis of the Vulcano and Nysiros island: clues of the definitions of their volcanic landforms. In Geovannelli, F. (ed.), Proceedings of International Workshop, "The bridge between Big bang and Biology", Stromboli (Messina, It), 13-17 September, 1999, CNR President's Bureau of the National Research Council, Special Volume, pp. 310-320.

Rodenkirchen, K. (2002). Assessing forests and community water sources of the Obudu Plateau. Prepared for The Biodiversity Research Programme, Nigerian Conservation Foundation (NCF) - Wildlife Conservation Society (WCS). Retrieved from http://programs.wcs.org/DesktopModules/Bring2mind/.../Download.aspx

Sim, J., \& Wright, C. C. (2005). The kappa statistics in reliability studies: use, interpretation and sample size requirements. Physical Therapy, 85, 257-268.

Strahler, A. H., Logan, T. L., \& Bryant, N. A. (1978). Improving forest cover classification accuracy form 
Landsat by incorporating topographic information. Proceedings of the 12th International Symposium on Remote Sensing of the Environment, 927-942.

Tate, N. J., \& Wood, J. (2001). Fractals and scale dependencies in topography. In Tate, N. J and Atkinson, P. M (Eds.), Modelling scale in geographical information science, (35-51), Wiley: Chichester.

Udofia, E. P. (2011). Applied statistics with multivariate methods. Enugu: Immaculate Publications Ltd.

Wood, J. D. (1996). The geomorphologic characterisation of digital elevation models (Unpublished doctoral dissertation), University of Leicester, UK.

Young, A. (1972). Slopes. Edinburgh: Oliver and Boyd.

Zevenbergen, I. W., \& Thorne, C. R. (1987). Quantitative analysis of land surface topography. Earth Surface Processes and Landforms, 12, 47-56. http://dx.doi.org/10.1002/esp.3290120107

\section{Copyrights}

Copyright for this article is retained by the author(s), with first publication rights granted to the journal.

This is an open-access article distributed under the terms and conditions of the Creative Commons Attribution license (http://creativecommons.org/licenses/by/3.0/). 